\title{
SROVNÁNÍ KATOLICKÝCH A EVANGELICKÝCH RUKOPISNÝCH MODLITEBNÍCH KNIH Z OBDOBÍ 18. - 1. POLOVINY 19. STOLETÍ ${ }^{1}$
}

\author{
Comparison of Catholic and Protestant Handwritten Prayer Books \\ From the 18th - the 1st Half of the 19th Century
}

\author{
Anna Holešová - Lenka Horáková
}

DOI: 10.17846/CL.2020.13.1.155-166

\begin{abstract}
HOLEŠOVÁ, Anna - HORÁKOVÁ, Lenka. Comparison of Catholic and Protestant Handwritten Prayer Books From the 18th - the 1st Half of the 19th Century. The article focuses on handwritten prayer books, which represent a significant phenomenon in the context of religious reading in $1750-1850$. The research is based on studies of twenty manuscripts of Czech and Moravian origin stored in museums and libraries. Attention is paid to a detailed analysis and a reciprocal comparison of handwritten Catholic and Protestant prayer books. It follows their physical form and examines the illustrations. It emphasises the content structure of books including the use of Biblical quotes. It introduces the way of creating texts and the relationship of manuscripts to their printed templates. It puts the topic in a socio-historical context. It also notes different roles of the handwritten prayer book in everyday life of the faithful of two confessions, as well as the indisputable importance in the Baroque folk piety.
\end{abstract}

Keywords: manuscripts, prayer books, Catholicism, Protestantism, folk religiosity

Abstrakt: HOLEŠOVÁ, Anna - HORÁKOVÁ, Lenka. Porovnanie katolíckych a evanjelických rukopisných modlitebných kníh z obdobia 18. - 1. polovice 19. storočia. Článok sa zameriava na rukopisné modlitebné knihy, ktoré predstavujú významný fenomén v kontexte náboženského čítania v rokoch 1750 - 1850. Výskum sa opiera o štúdie dvadsiatich rukopisov čes-

1 Článek je výstupem projektu Specifického výzkumu FF UHK za rok 2018. Vychází z disertační práce (Horáková 2010) a diplomové práce (Holešová 2017). K podrobné analýze byly metodou sondy vybrány reprezentativní vzorky katolických a evangelických modlitebních knih. Studium je podloženo výzkumem evangelických rukopisů uložených v Městském muzeu a galerii Polička (MMG, RKPST, [Písně a modlitby evangelické], sign. K 31; [Modlitby roční evangelické], sign. K 47; Modlitby křestanské od Jana Salatnay staršího kazatele Slova Božího v církvi evangelické hel[vétského] vy[znáni], sign. K 65; Modlitby nábožné pro čest a chválu Boží a spasení duše, sign. K 66; [Modlitebni knižka a žalmy], sign. K 67) a v soukromém archivu Bolom-Kotari (ABK, Modlitby horlivé $z$ Písem svatých vybrané s dovolením cís[aře] král[e] pro křestana reformitského náboženství, sign. 1; Modlitby nábožné pro čest a chválu Boží a spasení duše, sign. 2). Zkoumané katolické rukopisy pocházejí z Moravské zemské knihovny v Brně (MZK, RKPST, Toto duchovní křestansko-katolické jádro, sign. 1149-280; Výborné duchovní cvičení, sign. 1148-298; Bưh jest nejčist[š]í láska, sign. 0972.764; [Česká modlitební knížka], sign. 1149.282, 1149.283; Modlitby nábožné pro krestany katolické, sign. 1149-287; Dobrota Boží, sign. 0906.666), Slováckého muzea v Uherském Hradišti (SM, Poklad duše, sign. H 1204; Rajská růže vonnými modlitbami naplněná, sign. H1213; Studnice vod, vod živých, sign. H1222) a Muzea v Ivančicích (MI, Nábožné modlitby k Nejsvětější Trojici Božské, sign. IR2). 
kého a moravského pôvodu uchovávaných v múzeách a knižniciach. Pozornost̉ je venovaná detailnej analýze a vzájomnej komparácii rukopisných katolíckych a evanjelických modlitebných kníh. Sleduje ich fyzickú podobu a skúma ilustrácie. Kladie dôraz na obsahovú štruktúru kníh vrátane použitia biblických citácií. Uvádza spôsob tvorenia textov a vztahah rukopisov k ich tlačeným predlohám. Zasadzuje tému do spoločensko-historického kontextu. Všíma si tiež rozdielne úlohy rukopisnej modlitebnej knihy v každodennom živote veriacich oboch konfesií, ako aj nesporný význam v barokovej ludovej zbožnosti.

Klúčové slová: rukopisy, modlitebné knihy, katolicizmus, protestantizmus, ludová zbožnost'

\section{Obecné pojednání o modlitebních knihách}

Knihy byly psány pro venkovské obyvatelstvo př́slušníky místních intelektuálních elit, nejčastěji učiteli, faráři a písmáky, kteří si touto činností přivydělávali na živobytí. Autoři vycházeli většinou z tištěných předloh, $\mathrm{z}$ nichž podle svého uvážení vybírali modlitby, které bud' převzali doslova, nebo je modifikovali.

Modlitební kniha sloužila prostému člověku jako průvodce životem, pevně spjatým s křestanskou vírou. Modlitby byly pro věřícího nepostradatelnou součástí každého dne. Poskytovaly nejen spojení s Bohem a Kristem, ale obsahovaly i biblické citáty, které upevňovaly morálku a víru člověka. Katolíci chápali modlitební knihy jako individuální záležitost a pomůcku v průběhu mše svaté sloužené v latinském jazyce. Venkovský člověk latinu neovládal, proto byly modlitební knihy psány řečí, které rozuměl. Pro evangelíky $\mathrm{v}$ předtoleranční době, kdy nekatolictví nemělo institucionální podobu a vyznávání jiné, než katolické víry bylo oficiálně zakázáno, představovaly tyto knihy mnohdy jediný prostředek k uchování víry.

Modlitební kniha pro svého vlastníka neplnila jen funkci náboženského předmětu, kterému byly někdy přisuzovány magické vlastnosti (Nešpor 2009, 53), ale sloužila i jako zápisník či kronika. Údaje v ní zapsané mohou pomoci badatelům k identifikaci vlastníků knih a k rekonstrukci dějin každodennosti venkovských obyvatel. Na př́deštích a předsádkách knih se nejčastěji nalézají rukopisné provenienční záznamy a poznámky genealogického, hospodářského a pamětního charakteru. To, že si vlastníci zapisovali pro ně důležité údaje do modlitebních knih, svědčí o významném postavení tohoto rukopisného média. Modlitební knihy byly uloženy nejčastěji $\mathrm{v}$ „koutnici“, malované skříňce $\mathrm{v}$ rohu světnice za lavicí spolu s cennostmi, knihami a rodinnými dokumenty (Bolom-Kotari 2008, 133-134).

Katolické i evangelické rukopisné modlitební knihy byly nejvíce rozšířeny ve 2. polovině 18 . a v 1. polovině 19. století. Jednalo se o jistý projev barokní zbožnosti, který mezi laiky přetrvával i v době osvícenství. Od 2. poloviny 19. století poptávka po rukopisných modlitebních knihách klesala ve prospěch tisků. U evangelíků si to můžeme vysvětlit tím, že po zrovnoprávnění evangelické církve s katolickou roku 1861 pozbývaly rukou psané modlitební knihy význam. Již nebylo nutné zachovávat dř́ve tajnou a později tolerovanou víru, a proto se v novém vnímání světa jevily jako nemoderní a zastaralé (Nešpor 2009, 53). Faktem ale je, že nové rukopisné katolické modlitební knihy v tomto období již také nevznikaly.

Zájem veřejnosti o rukopisné modlitební knihy jako o dokladu folkloru českého venkova probudila Národopisná českoslovanská výstava v Praze roku 1895 (Matějková 1896, 321-323). V národopisném časopisu Český lid vycházely od konce 19. století drobné př́spěvky s úryvky modliteb zaměřující se pouze na grafickou stránku. ${ }^{2}$

2 Např́íklad (Matějka 1893, 584-588; Racek 1901, 26-30; Zíbrt 1905, 183-185; Adámek 1895, 483-492). 
Modlitební knihy byly a jsou roztroušeny ve fondech muzeí, knihoven či archivů. Stovky exemplářu se pravděpodobně nacházejí v soukromém vlastnictví. Díky sběratelské činnosti se do dnešní doby zachovalo množství čítající tisíce knih. ${ }^{3}$

$\mathrm{V}$ novější době se fenomén rukopisných modlitebních knih at už katolických nebo evangelických stal předmětem zájmu mnoha autorů, kteří se soustředí kromě výtvarného zpracování i na obsahovou složku. ${ }^{4}$

Studium rukopisných modlitebních knih není doposud uzavřeno, přestože o tématu bylo napsáno již více prací. Téma lze zkoumat nejen z pohledu lidové zbožnosti a každodennosti, ale i z pohledu teologie, filologie, etnografie či hymnografie.

\section{Význam četby}

$\mathrm{Na}$ evangelickou víru měla vždy velký vliv četba knih. Psané, mluvené či zpívané slovo prohlubovalo a kultivovalo náboženské smýšlení nekatolíků již v předbělohorské době. Lidé žijící na venkově často vlastnili náboženskou literaturu, která se ke katolíkům př́liš nedostávala. ${ }^{5}$ Neexistence institucionální nekatolické církve, a zvláště období rekatolizace zapříčinily, že ručně psané či tištěné knihy byly jediným prostředkem k uchování víry. Jejich četba nahrazovala kázání (Nekvapil 2015, 142-143). Nekatolíci četli texty $\mathrm{z}$ bible, postil nebo modlitebních knih v soukromí, v rodinném kruhu, nebo ve větších shromážděních. (Andrlová Fidlerová 2013, 391). Mnozí z nich tak znali nazpamět celou řadu biblických pasáží. Samostudium však s sebou neslo riziko dezinterpretace a nepochopení významu textu (Svatoš 2003, 364-365).

Katolická církev považovala nekatolíky za kacíře, které bylo nutno přivést zpět k samospasitelné viŕre. Usilovala o zamezení šiření závadných myšlenek a snažila se o zajištění jednotného náboženského smýšlení obyvatelstva. Jedním z nástrojů rekatolizace probíhající po roce 1620 bylo zesílení kontroly nad obyvatelstvem a s tím spojené postihy za vyznávání jiné než katolické víry i pod pohrůžkou trestu smrti. ${ }^{6}$ Dále se jednalo např́iklad o misie vysílané na venkov, násilné přesídlování nebo zabavování nepovolených knih (Svatoš 1999, 364-369).7 Úspěšnost těchto opatření nebyla ve všech oblastech Koruny české stejná. Lišila se místními podmínkami jako je terén, hustota osídlení a míra kontaktu s nekatolíky z okolních zemí. Nekatolíci měli k dispozici množství náboženských knih, které se $\mathrm{v}$ rodinách dědily $\mathrm{z}$ generace na generaci. Knihy kupovali ze zahraničí, opisovali či dostávali od tajných kolportérů z ciziny. ${ }^{8}$ Mezi oblíbené tituly předtoleranční náboženské literatury patřily například Stránského Zahrádka duchovní (1576), Ruční knižka Kašpara Motěšického (1687), Perlička ditek Božích Sixta Palma Močidlanského (1619), Zahrádka rajská (1612) Johanna Arndta, Kleychovy Vroucí a nábožné modlitby (1720), Křestanské naučení a modlitby podle rozličných stavů

3 Soukromá sbírka sběratele Karla Adámka se nachází v Hlinsku. Soubor analyzoval Zdeněk R. Nešpor.

4 Tématem evangelických rukopisných modlitebních knih se zabývali (Nešpor 2007, 225-256; Bolom-Kotari 2016, 74-89; Vorlíčková 2010, 5-50; Andrlová Fidlerová 2013, 385-408). Katolickým modlitebním knihám se věnovaly (Šimková 2009; Holubová 2001, 33-41; Horáková 2009, 179-187; Kuchařová 2009, 263-287).

5 Jezuité založili vydavatelství Dědictví svatováclavské až roku 1669 (Svatoš 2003, 369).

6 Císař Karel V. vydal roku 1707 mandát, v němž označil kacířství za zločin proti státu, které má být trestáno na hrdle (Melmuková-Šašecí 2013, 84).

7 Známý jezuita Antonín Koniáš zabavil kolem tří tisíc knih východočeským nekatolíkům. Roku 1729 vyšla tiskem v Hradci Králové př́ručka určená k vyhledávání kacířských knih Kljč Kacýřské Bludy K rozeznánj otwjragjcý. O tématu dále (Mikulec 1992).

8 Nešpor vyzdvihuje ediční činnost zahraničních predikantů a význam Hallské bible vydané v letech 1722, 1745, 1766. (Nešpor 2005, 231-258). 
a potřeb křestanského člověka pripravené od Jiř́ka Sixaye (1795), Komenského Praxis Pietatis (1630), kancionály či tzv. Hojky (Burian - Melmuk - Melmuková-Šašecí 1995-1996, 294-295).

Zásadní vliv na zachování nekatolictví na území Čech měla emigrantská střediska a propracovaná informační sít nekatolíků, kteři žili většinou na těžko dostupných místech, např́íklad v oblastech Českomoravské vysočiny a Valašska. Predikanti přinášející duchovní potravu přicházeli z prostředí nakloněného protestantům, z Pruska, Saska, Polska a Uher (Melmuková-Šašecí 2013, 74-78).

Zcela jiným způsobem bylo nahlíženo na četbu u katolíků. Díky tomu, že účast na mši svaté byla pro věŕící povinná, neměla četba pro příslušníky této konfese tak obrovský význam a mnohem větší důraz byl kladen na mluvené slovo. Docházelo i k pochybnostem, zda je pro věŕící $\mathrm{v}$ rámci jejich víry př́nosná, nebot mohlo dojít ke špatnému pochopení textu. Spíše byla chápána jako náhrada $\mathrm{v}$ případě, že se věrící nemohl zúčastnit osobně mše svaté, nebo byla brána jako doplněk práce kněze (Malura 2015). Přesto od 2. poloviny 18. století nabývala četba v každodenním životě věřících na významu. Pomocí knih mohli věřící vyplnit svůj volný čas modlitbami a rozjímáním o viřre (Bočková 2009,12-37). Snad i proto se začínají stále více šiřit přepisy tištěných modlitebních knih v nejrůznějších podobách.

Mezi nejoblíbenější tištěné katolické modlitební knihy, které byly přepisovány, dlouhodobě patřila díla německého kapucína Martina z Kochemu Malá štěpná zahrádka, Velká štěpná zahrádka a Nebeklíč, od Karla von Eckartshausena Bưh jest nejčistši láska, dále anonymní díla Studnice vod živých, Rajská růže vonnými modlitbami naplněná a mnohé další.

\section{Toleranční doba}

Toleranční patent vydaný císařem Josefem II. na podzim roku 1781 znamenal zlom v dosavadním vývoji církevní správy. Oficiálně byla ustanovena tři vyznání, augšpurské, helvétské a pravoslavné. Katolická církev si nadále uchovala vedoucí roli, zatímco nově konstituované církve s nerovnoprávným postavením byly pouze tolerovány do vydání Protestantského patentu roku $1861 .{ }^{9}$ Čeští nekatolíci vstupovali častěji do reformované helvétské církve, protože se prosté a strohé učení kalvínského typu lpějícím na tradicionalismu podobalo víre jejich otců a učení Jednoty bratrské. Luterány se naopak stávali většinou obyvatelé hovořící německy a polsky. Vnějšími projevy připomínalo luterství katolicismus, ${ }^{10}$ který helvéti odmítali (Nešpor 2006, 392-395).

Postupně docházelo ke vzniku a konsolidaci sborů s presbytery a jejich kurátory, ustanovení vídeňské konzistoře, superintendencí a výstavbě modliteben. Kvưli nedostatku nekatolického duchovenstva přicházeli do českých zemí kazatelé z Uher, kteří se také starali o duchovní literaturu ve sborech. Někteří z nich byli literárně činní, psali kázání, modlitby, polemiky, katechismy, kroniky sboru nebo překládali cizojazyčná díla. ${ }^{11}$ Institucionalizace evangelické církve s sebou nutně přinášela i potřebu zavést oficiální evangelickou náboženskou literaturu. Zde se však projevil

9 Evangelíků se týkala řada omezení. Museli až do roku 1861 absolvovat šestinedělní cvičení, které je mělo přimět konvertovat ke katolictví. Katolický farář vedl matriky a evangelíci mu museli nadále odvádět štolu. Navíc si sbory sami financovali faráře a učitele, což představovalo velkou zátěž. Modlitebny se mohly stavět pouze v místech, kde žilo 100 rodin nebo 500 duší. Pro stavbu modlitebny platila řada omezení. Nesměla mít věž, aby nepřipomínala katolický kostel, vchod musel být situován mimo veřejné cesty. Více (Burian - Melmuk - Melmuková-Šašecí 1995-1996, 28).

10 Luterští faráŕi používali hostie a kříže, zpěvníky obsahovaly litanie.

11 Pastor János Végh (1755 - 1830), působící v Libiši, Lysé a v Nebuželích vydal kromě řady kázání roku 1783 český překlad Václava Matěje Krameria a Josefa Szalaye Krátké a sprosté vyznání a vysvětlení víry čisté křestanské, dále Agendu, vzorovou příručku pro bohoslužby. Moravečský pastor János Szalatnay (1758 1827) byl autorem modliteb a kroniky moravečského sboru. Více (Toul 1931). 
konzervatismus evangelíků, kteří se nechtěli vzdát předtolerančních knih, ve kterých viděli záruku správného výkladu víry (Burian - Melmuk - Melmuková-Šašecí 1995-1996, 112).

\section{Srovnání vnějších znaků katolických a evangelických rukopisných modlitebních knih}

Katolické a evangelické rukopisné modlitební knihy se po fyzické stránce od sebe príliš neliší. Nalezneme $\mathrm{v}$ nich řadu shodných prvků, které poukazují na to, že knihy podléhaly dobovému vývoji. Již na první pohled je znatelné, že knihy měly své uživatele najít mezi chudší vrstvou obyvatel bez ohledu na jejich vyznání. Rukopisy bývaly menšího, tzv. osmerkového formátu a byly vevázány v jednoduché kožené nebo papírové vazbě. Zdobená byla velmi skromně, a to jednoduchou slepotiskovou nebo zlacenou linkou, občas nacházíme na deskách vazby zlacené iniciály, letopočet nebo $\mathrm{v}$ prrípadě evangelických knih motiv kalicha. Rukopisné knihy byly psány na papíre. Identifikace papíren, $\mathrm{v}$ nichž byl papír vyroben, se nepodařila, nebot' u většiny rukopisů filigrány bud' chybí, nebo díky malému formátu papíru nalezneme jen jejich část.

K dalšímu shodnému znaku obou typů modlitebních knih patří písmo, které se v rukopisech vyskytuje. Pro 18. a 1. polovinu 19. století je typické používání německého novogotického písma, respektive jeho tří podob - kresleného písma Frakturaschrift, polokurzivy Kanzleischrift a kurzivy Kurrentschrift. Jejich užívání bylo dáno praktickou potřebou písaře zdůraznit různé pasáže textu. Běžně se psalo tzv. kurentem, tedy svižným písmem s plně propojenými tahy a výrazným sklonem doprava. Pro zvýraznění textů se používaly první dvě zmiňované alternativy, fraktura pro nadpisy a kanzlei pro zdůraznění různých pasážích $\mathrm{v}$ textu. V případě zvýraznění názvu modlitby nebo i jejich prvních několika slov frakturou písaři plynule pokračovali v textu písmem kanzlei, které dále př̀echázelo v běžný kurent.

Stejně jako u diplomatických písemností se i zde setkáváme s humanistickou kurzivou v př́padě latinských termínů Credo, Sanctus. Písaři některých rukopisných knih měli tendenci co nejvěrněji kopírovat knihy, které jim sloužily jako vzor. Za tímto účelem napodobovali tiskové písmo, takže vznikl zcela odlišný typ písma, který se uplatnil pouze v rukopisech, tzv. kreslená forma tiskového písma švabach. Šlo o značně kaligraficky propracované písmo, které napodobovalo tahy jednotlivých liter tištěného švabachu. S takovýmito rukopisy se však setkáváme spíše výjimečně.

Důležitou částí rukopisů byla jejich výzdoba, na které se podíleli sami písaři. Záleželo pouze na nich, jakou váhu jim přiklonili. Celkový charakter rukopisů i jejich vnitřní dekorace působily prostě a jednoduše. Díky tomu, že písaři nebyli profesionálními ilustrátory, nedosahovala umělecká úroveň rukopisů vysoké kvality.

Mezi běžné prvky výzdoby katolických i evangelických rukopisných modlitebních knih patřily kaligraficky provedené titulní listy a nadpisy jednotlivých modliteb, stránky ohraničené černou linkou nebo pestrým kolorovaným rámečkem, př́padně barevná paginace. Texty modliteb mohly doplňovat kresby, zpravidla na konci kapitoly, které vyplňovaly prázdný konec stránky. Většinou se jednalo o květinové motivy, u katolických modlitebních knih pak o anděly nebo putti. Tyto drobné kresby připomínají viněty, které byly velmi oblíbeným prvkem dekorace u starých tisků.

Ilustrace, at už celostránkové či drobnější na začátku, nebo na konci modlitby, se už mohly $\mathrm{v}$ rámci obou konfesí lišit. $\mathrm{V}$ souvislosti s evangelickým pojetím víry bývaly zobrazovány motivy vztahující se bezprostředně k Bohu a ke Kristu jako např́ílad srdce, pelikán, kalich, desky Desatera, modlitebna. Evangelíci však striktně dbali na dodržování prvního přikázání Neučiniš sobě rytiny, ${ }^{12}$ zapovídající zhotovovat hmotná zobrazení Boha. Odmítali jim úctu, nebot' to

12 Viz (Bolom-Kotari - Kotlíková 2010; Bolom-Kotari 2012, 5-7). 
považovali za projev modlářství (Burian - Melmuk - Melmuková-Šašecí 1995-1996, 305). Stejně tak nenalezneme v evangelických modlitebních knihách světce, mariánský kult a kříže, tolik signifikantní a oblíbené pro katolické prostředí.

Naproti tomu nacházíme mezi katolickými modlitebními knihami mnoho takových, v nichž se objevují celostránkové ilustrace. Často se v rukopisech vyskytuje motiv Ukřižování, většinou bezprostředně před titulním listem, plnící funkci frontispisu, nebo uvozující novou část modliteb. Oblíbené jsou také celostránkové ilustrace světců, mezi nimiž se objevuje Panna Maria, často zobrazována jako Panna Maria Mariazellská, dále sv. Kateřina, sv. Barbora, sv. Florian, sv. Jan Nepomucký, sv. Antonín, sv. Jan Křtitel.

\section{Obsahové srovnání katolických a evangelických modlitebních knih}

Autoři katolických i evangelických modlitebních knih, kteří byli současně i jejich písaři, nebyli autory v pravém slova smyslu. Převážná část modliteb byla přepsána $\mathrm{z}$ tištěných předloh a můžeme se spíše jen dohadovat o tom, zda některé modlitby byly skutečně originálním počinem autora rukopisu. Písaři katolických modlitebních knih své dílo sestavili zpravidla výběrem modliteb z jedné, někdy i z více tištěných modlitebních knih. Pro evangelíky byla také základem tištěná modlitební kniha, své dílo ale často obohacovali o úryvky z kancionálů a bible. Záleželo na libovůli písaře, které modlitby zařadí do svého rukopisu a do jaké míry zachová jejich přesné znění. Pro modlitební knihy však bylo společné to, že měly být průvodcem křestana v průběhu celého dne, a proto reflektovaly nejdůležitější části této základní časové jednotky každého člověka. Všechny knihy byly proto strukturovány do několika skupin vztahujících se k denním dobám. Počátek a konec dne uvozoval křestan pravidelnými modlitbami, aby vzdal díky Bohu za prožitý den a klidnou noc, tzv. modlitbami ranními a večerními. Nedílnou součástí základní obsahové části každé rukopisné modlitební knihy byly modlitby doprovázející křestana při bohoslužbě. $\mathrm{V}$ př́padě katolických modlitebních knih to jsou tzv. modlitby ke mši. Modlitby této skupiny patřily mezi nejpočetnější. Představovaly návod, jak se měl věrící při bohoslužbě modlit. Takováto pomůcka byla důležitá pro katolíky, kteří se účastnili latinské mše. Prostí lidé jí nemohli rozumět, pouze kázání mohlo probíhat v národních jazycích. Modlitby plně respektovaly průběh bohoslužby. V katolických modlitebních knihách proto nacházíme konkrétní modlitby pojmenované podle částí mše svaté, a to od přípravné části mše svaté až po její závěr: Introitus, Kyrie, Gloria, Orace (kolekta), epištola, evangelium, Kredo, ofertorium, modlitby při obětování, okuřování, umývání rukou, sekreta, preface, Sanktus, kánon, modlitby před proměňováním, proměňování a pozdvihování, modlitby po proměňování. Graficky byly od těchto modliteb odděleny modlitby zpovědní a $k$ prijímání (Horáková 2010, 225). Evangelíci v toleranční době také používali modlitební knihu jako pomůcku při bohoslužbě konané úředně schváleným kazatelem. Názvy modliteb označují její jednotlivé části prèed kázáním, po kázání, před zpovědí, po zpovědi, před prijímáním Večěre Páně, po prìijimání Večeře Páně. Na rozdíl od katolické zpovědi, kdy hříšník vyznával své hříchy Bohu prostřednictvím kněze, se evangelík zpovídal osobně ve své modlitbě.

$\mathrm{V}$ rukopisech se běžně setkáváme $\mathrm{s}$ citáty $\mathrm{z}$ bible, a to především $\mathrm{v}$ helvétských modlitebních knihách. Hluboká a rozšířená znalost biblických textů v evangelické komunitě se projevovala v jejich hojném citování či parafrázování. Mezi nejoblíbenější citované pasáže z knih Starého Zákona patř́i knihy Job, Žalmy, Př́sloví, Jeremiáš, Izajáš, pět knih Mojžíšových. Objevují se i citáty z dalších starozákonních knih. ${ }^{13}$ Zajímavé jsou i časté úryvky z apokryfní knihy Judit. ${ }^{14}$ Biblické citáty

13 Např́íklad 1. a 2. kniha Královská, 1. a 2. kniha Samuelova, 2. Paralipomenon, Ezechiel, Zachariáš, Sofoniáš, Jonáš.

14 Podle katolické církve se kniha Judit řadí mezi deuterokanonické knihy. Citované jsou zvláště kapitoly 7 a 9 (Bič 1996, 48-69). 
s odkazy na konkrétní knihy sloužily nejen k vyučování, ale i k posílení ve víře. Na křestana jistě zapůsobily př́běhy těžce zkoušeného Joba, který i přes všechno utrpení Boha nezatracoval, ale miloval jej (MMG, RKPST, Modlitby nábožné pro čest a chválu Boží a spasení duše, sign. K 66, 45-46; ABK, Modlitby nábožné pro čest a chválu Boží a spasení duše, sign. 2, 47-53). Novozákonní citáty vychází ze čtyř Evangelií Matouše, Marka, Lukáše a Jana.

V př́ipadě katolických rukopisných modlitebních knih nejsou citáty z Bible ani zdaleka tak četné. Pravidelněji se vyskytují v rukopisech pouze úryvky z Evangelia sv. Jana a žalmy. Mnohem více oblíbené byly u katolíků litanie, které známe pouze v rámci této konfese. Ve své oficiální podobě vychází litanie z breviáře, konkrétně se jedná o Litanie ke všem svatým. Tyto prosebné modlitby se staly zejména $\mathrm{v}$ novověku značně populární a z oficiální liturgické příručky se postupně dostaly v národních jazycích do podvědomí laické veřejnosti, takže v 16 . století bylo známo již více než osmdesát litanií (Berger 2008, 245). Písaři je pravidelně zařazovali do svých rukopisů. V rámci různých druhů litanií pozorujeme, jak důležitý byl pro křestany po celou dobu vzniku modlitebních knih kult Panny Marie. Nejvíce zastoupené byly Litanie loretánské, případně i jiné mariánské. Kromě nich zde nacházíme litanie určené Ježíši Kristu, např́klad Litanie o přehořkém Umučení a smrti Pána Ježíše Krista a Litanie ke všem svatým.

Různé projevy úcty k Panně Marii a ke svatým byly pro barokní katolickou zbožnost velmi důležité. Např́íklad pro venkovský lid bylo uctívání svatých konkrétním předmětem $\mathrm{v}$ jejich víre, chápali je jako ty, kteří se za ně přimluví u Boha. S nástupem osvícenství však začala být tato tradice potlačována. Přesto v lidové zbožnosti, a tedy i v modlitebních knihách projevy této úcty ještě dlouho přetrvávaly (Zuber 2003, 279-280). V rukopisných katolických modlitebních knihách nacházíme celou řadu modliteb ke svatým po celou dobu jejich trvání, tedy i v 1. polovině 19. století. Stejně jako litanie i modlitby byly nejčastěji věnovány kultu Panny Marie. Mezi další oblíbené světce patřila sv. Anna, sv. Josef, sv. Antonín Paduánský, sv. Šebastián, sv. Roch, sv. František, sv. Barbora, sv. Kateřina, sv. Apolena, sv. Brigita a sestry sv. Gertruda a sv. Mechtylda. Jako př́mluvci u Boha byli také zmiňováni sv. Jan Nepomucký a sv. Václav, jejichž úcta je vázána regionálně na české země. Kult těchto dvou světců nepřevyšoval v počtu modliteb ostatní svaté. Je trochu překvapující, že se v modlitebních knihách nevyskytují běžně slovanští světci. Zcela výjimečně se objevuje pouze modlitba ke sv. Cyrilu a Metodějovi, v modlitební knize zmiňovaní jako Crha a Strachota, apoštolové moravští (Baručáková 2005, 35-36). Některé modlitby nebyly věnovány konkrétnímu světci, ale místo jeho jména stálo označení $N$. $N$. Věřící si sám mohl doplnit svého oblíbeného světce, kterému chtěl věnovat svou prosbu.

Dalším typickým rysem lidové barokní zbožnosti byly oslavy velkého množství svátků a slavností, které provázely věřící v průběhu celého roku. Tyto významné události měly kromě náboženského významu i společenský aspekt. Lidé se scházeli při bohoslužbách v kostelích a modlitebnách, nebo se setkávali u rodinného stolu (van Dülmen 2007, 123). V rámci obou konfesí sledujeme jiný přístup v tom, které svátky a jakým způsobem byly slaveny.

Katolické svátky zahrnovaly množství slavností a pobožností, například svátky Božího Těla, Nanebevstoupení Panny Marie, Nejsvětějšího Srdce Ježíšova nebo slavnosti Neposkvrněného početí Panny Marie, Všech svatých a podobně (Zuber 2003, 245-253). Modlitby věnované svátkům nacházíme hlavně v tištěných katolických modlitebních knihách, které byly předlohou pro rukopisy (Knihopis, Studnice Wod Žiwych, Znojmo [1743-1787], č. K15779a, 354393; Duchovní křestansko-katolické jádro všech modliteb, Brno 1778, 144-151). V rukopisech jejich přepisy chybí. Stejně tak zde nejsou modlitby, které byly doporučené při poutích nebo při procesích.

Svou typickou obřadností se výrazně odlišovaly od evangelických svátků. Evangelíci tíhli $\mathrm{k}$ prostším obřadům, zdůrazňovali niternost prožitku s důrazem na četbu Písma svatého, které považovali za jedinou autoritu. Odmítali velkolepé slavnosti, svátky spojené s kultem svatým, 
mariánským kultem, nebo zázraky, které byly tolik vlastní druhé konfesi (Nešpor 2006, 175). Evangelická víra byla pevně zakořeněná po generace v lidských srdcích, nebot mnozí nekatolíci zakusili v době protireformace pronásledování a náboženský útlak (Melmuková 2013). I přes tuto rozdílnost, slavily obě konfese v průběhu církevního roku nejdůležitější křestanské svátky Vánoce - Velikonoce - Letnice, tedy festivity spjaté s důležitými událostmi ze života Ježíše Krista (Večerková 2015, 11). V evangelických rukopisných modlitebních knihách je obecně svátkům věnováno málo prostoru. Vyskytují se v nich pouze modlitby vánoční, novoroční, velikonoční a svatodušní.

\section{Závěr}

Primární funkce katolických i evangelických rukopisných modlitebních knih byla praktická. Podle základní obsahové struktury, kterou $\mathrm{v}$ případě obou konfesí tvoří modlitby ranní, večerní a modlitby provázející věrícího během bohoslužby, je zjevné, že knihy plnily úlohu příručky při každodenní modlitbě. Zpravidla se nejednalo o originály modliteb, ale o přepisy z tištěných předloh. Tyto rukopisy měly i sekundární úlohu. Věřící si do nich psali různé záznamy, nejčastěji genealogického charakteru, méně často se jednalo o poznámky, které měly podobu kronikářských záznamů. Zásadní rozdíl mezi katolickými a evangelickými rukopisnými modlitebními knihami spočíval v jejich funkci. Katolíci měli své modlitební knihy spíše jako doplněk ke mši svaté, které se každý týden účastnili. Pro evangelíky před rokem 1781 představovaly modlitební knihy jeden z nejdůležitějších zdrojů k upevňování víry. Po vydání Tolerančního patentu sloužily též jako pomůcky při bohoslužbách.

\section{REFERENCES}

\section{Primary sources}

Archiv Bolom-Kotari (dále ABK), signatura (dále sign.) 1, 2.

Duchovni křestansko-katolické jádro všech modliteb, Brno 1778.

Knihopis českých a slovenských tisků od doby nejstarší až do konce XVIII. století (dále Knihopis), číslo (dále č.) K15779a.

Městské muzeum a galerie Polička (dále MMG), Oddělení rukopisů a starých tisků (dále RKPST), signatura (dále sign.) K 31, 47, 65, 66, 67.

Moravská zemská knihovna v Brně (dále MZK), Oddělení rukopisů a starých tisků (dále RKPST), signatura (dále sign.) 1149-280, 1149.298, 0972.764, 1149.282, 1149.283, 1149-287, 0906.666.

Muzeum v Ivančicích (dále MI), signatura (dále sign.) IR2.

Slovácké muzeum v Uherském Hradišti (dále SM), signatura (dále sign.) H1222, H1213, H1204.

\section{Secondary sources}

Adámek, Karel. 1895. Z národopisných výstav: Památky evangelíků ve východních Čechách. In Český lid IV, 483-492.

Andrlová Fidlerová, Alena. 2013. Lidové rukopisné modlitební knihy raného novověku. In Český lid 100/4, 385-408. 
Baručáková, Lenka. 2005. Katalog rukopisů MZK v Brně. Diplomová práce. Masarykova univerzita. Brno.

Berger, Rupert. 2008. Liturgický slovník. Praha.

Bič, Miloš. 1996. Výklady ke Starému zákonu, V. Knihy deuterokanonické (nekanonické, apokryfní), Kostelní Vydří 1996, s. 48-69.

Bočková, Hana. 2009. Knihy nábožné a prosté. K nábožensky vzdělávací slovesné tvorbě doby barokní. K nábožensky vzdělávací slovesné tvorbě doby barokní. Brno.

Bolom-Kotari, Sixtus. 2008. Tomáš Juren - Toleranční doba na Vysočině a hudba srdce. Brno.

Bolom-Kotari, Sixtus. 2012. Evangelické umění mezi neexistencí a zapomněním. In Protestant XXIII/5, 5-7.

Bolom-Kotari, Sixtus - Kotlíková, Martina - Kotlíková, Dagmar. 2010. Neučiníš sobě rytiny: evangelické umění toleranční doby 1781-1861. Katalog výstavy. Brno.

Bolom-Kotari, Sixtus - Bolom-Kotari, Martina. 2016. Evangelické modlitební knihy 18. a 19. století a česká bible. [Protestant Prayer Books from the 18th and 19th Centuries and the Czech Bible]. In Konštantínove listy [Constantine's Letters] 9/2, 74-89.

Burian, Ilja - Melmuk, Jiří - Melmuková-Šašecí, Eva. 1995-1996. Evangelíci v Čechách a na Moravě, Praha 1995-1996, s. 294-295.

van Dülmen, Richard. 2007. Kultura a každodenní život v raném novověku (16. - 18. století). Vesnice a město, II. Praha.

Holešová, Anna. 2017. Fenomén evangelických rukopisných modlitebních knih z 19. století. Diplomová práce. Univerzita Hradec Králové. Hradec Králové.

Holubová, Markéta. 2001. „Duchovní pokládek duše křestanské“ aneb co vyprávějí rukopisné modlitební knížky 18 a 19. století. In Knihy a dějiny 3/2, 33-41.

Horáková, Lenka. 2009. Rukou psaná katolická modlitební kniha v 18. a v první polovině 19. století. In Východočeské listy historické 26, 179-187.

Horáková, Lenka. 2010. Vývoj novověkých rukopisně tradovaných modlitebních knih na území jižní Moravy. Disertační práce. Masarykova univerzita. Brno.

Kuchařová, Hedvika. 2009. Několik poznámek k modlitebním knihám 18. a 19. století. In Listy filologické 3-4, 263-287.

Malura, Jan. 2015. Meditace a modlitba v literatuře raného novověku. Ostrava.

Matějka, Jan. 1893. Malované modlitební knihy z XVIII. a ze začátku XIX. století. In Český lid II, 584-588.

Matějková, Marie. 1896. Psané a ozdobené památky lidové na Národní výstavě v Praze. In Český lid V, 321-323.

Melmuková-Šašecí, Eva. 2013. Patent zvaný toleranční. Neratovice.

Mikulec, Jiří. 1992. Pobělohorská rekatolizace v českých zemích. Praha.

Nekvapil, Ladislav. 2015. Východočeští nekatolíci v době baroka a osvícenství: Chrudimský kraj v letech 1621-1781. Pardubice.

Nešpor, Zdeněk R. 2005. Bible českých exulantů a tajných nekatolíků v 18. století. In Revue pro religionistiku 13/2, 231-258.

Nešpor, Zdeněk R. 2006. Náboženství na prahu nové doby: česká lidová zbožnost 18. a 19. století. Ústí nad Labem.

Nešpor, Zdeněk R. 2007. „Vzduch k Bohu dychtíci“ Rozprava o (300) nepísňových lidových náboženských rukopisech z 18.-19. století. In Český lid 94/1, 225-256.

Nešpor, Zdeněk R. 2009. Lidové modlitební knížky 18. a 19. století. In Šimková, Anežka (ed.). Růžová zahrádka. Rukopisné modlitební knížky 18. a 19. století. Olomouc, 47-55.

Racek, František. 1901. O malovaných modlitebních knihách jihočeských. In Český lid X, 26-30. 
Svatoš, Martin. 2003. Kontrola četby a distribuce náboženských knih při lidových misiích a misijní knížky v 18. století. In Čornejová, Ivana (ed.). Úloha církevních řádů při pobělohorské rekatolizaci. Praha, 363-384.

Šimková, Anežka (ed.). 2009. Růžová zahrádka. Rukopisné modlitební knížky 18. a 19. století. Olomouc.

Toul, Jan. 1931. Jubilejní kniha českobratrské evangelické rodiny k 150letému jubileu tolerančního patentu 1781-1931. České Budějovice.

Večerková, Eva. 2015. Obyčeje a slavnosti v české lidové kultuře. Praha.

Vorlíčková, Anna. 2010. Modlitební kniha českých exulantů v Žitavě z roku 1706. In Knihy a dějiny $16 / 17,5-50$.

Zíbrt, Čeněk. 1905. Z východočeských psaných modliteb. In Český lid XIV, 183-185.

Zuber, Rudolf. 2003. Osudy moravské církve v 18. století. II. Olomouc.

\begin{abstract}
SUMMARY: COMPARISION OF CATHOLIC AND PROTESTANT HANDWRITTEN PRAYER BOOKS FROM THE 18TH - THE 1ST HALF OF THE 19TH CENTURY. Handwritten prayer books were most widespread in Bohemia and Moravia from the 18th to the 1st half of the 19th century. This genre of religious literature was found in almost every household in the country. The prayer book served as a family chronicle and a religious aid. The authors of prayer books were members of intellectual elites, such as teachers and pastors. They were inspired by the Bible, hymn books and printed prayer books. Texts from these inspirational sources were taken, edited and supplemented with illustrations. The manuscripts were made to order by wealthy people living in the country. The role of the prayer book varied in Protestant and Catholic communities. The differences were caused by religious situation, the position of Protestants in the state, access to reading, understanding of worship and the way of showing respect for God. Catholic piety characterized by the ceremony and worship of the saints was in stark contrast to the Protestant inner experience of faith and an emphasis on knowledge of the Holy Scripture. This attitude stemmed from the unequal position of both confessions before 1781, when the prayer book was often the only means of preserving faith for Protestants.
\end{abstract}

Mgr. Anna Holešová

Philosophical Faculty, University of Hradec Králové

Department of Auxiliary Historical Sciences and Archival Science

Náměstí Svobody 331

CZ-500 03 Hradec Králové

The Czech Republic

anna.holesova@uhk.cz

Mgr. Lenka Horáková, Ph.D.

Philosophical Faculty, University of Hradec Králové

Department of Auxiliary Historical Sciences and Archival Science

Náměstí Svobody 331

CZ-500 03 Hradec Králové

The Czech Republic

lenka.horakova@uhk.cz 


\section{Prílohy/Appendix}

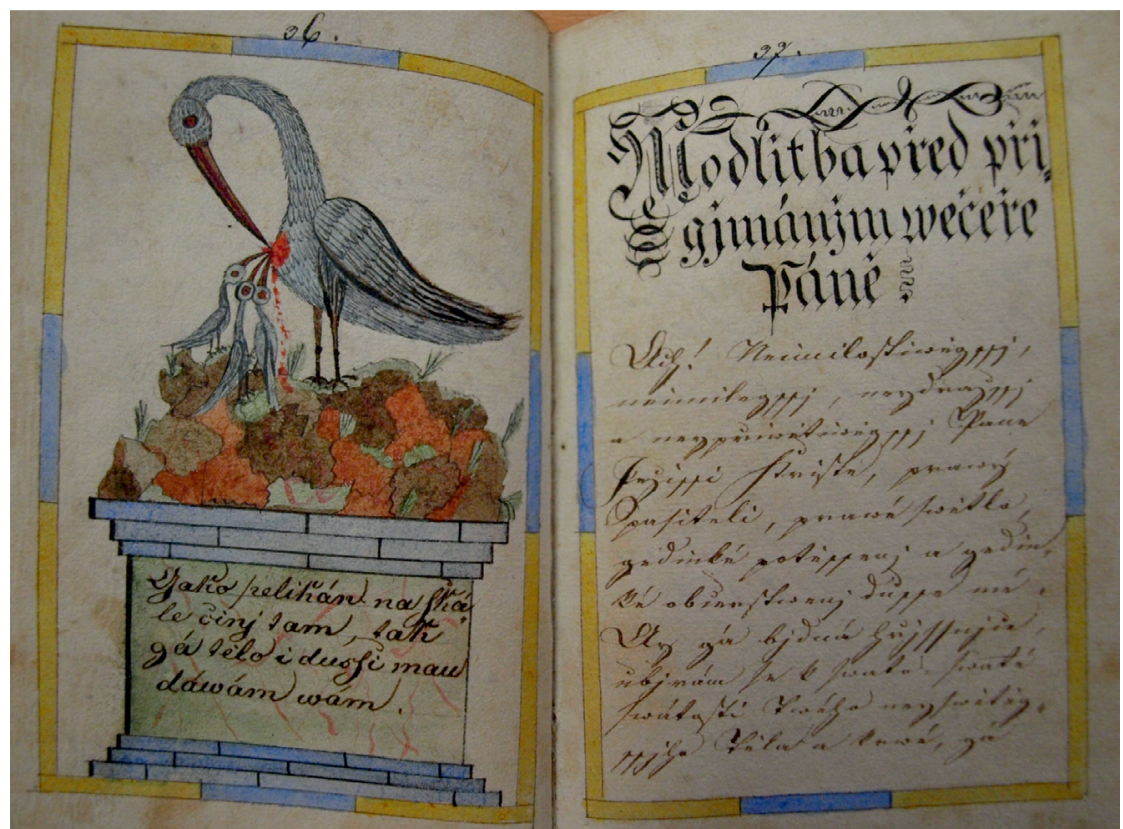

Obr. 1 Modlitba před přiímáním Večeře Páně (MMG Polička, RKPST, sign. K 65, s. 36-37).

Fig. 1 Prayer before the Lord's Supper (MMG Polička, RKPST, sign. K 65, p. 36-37).

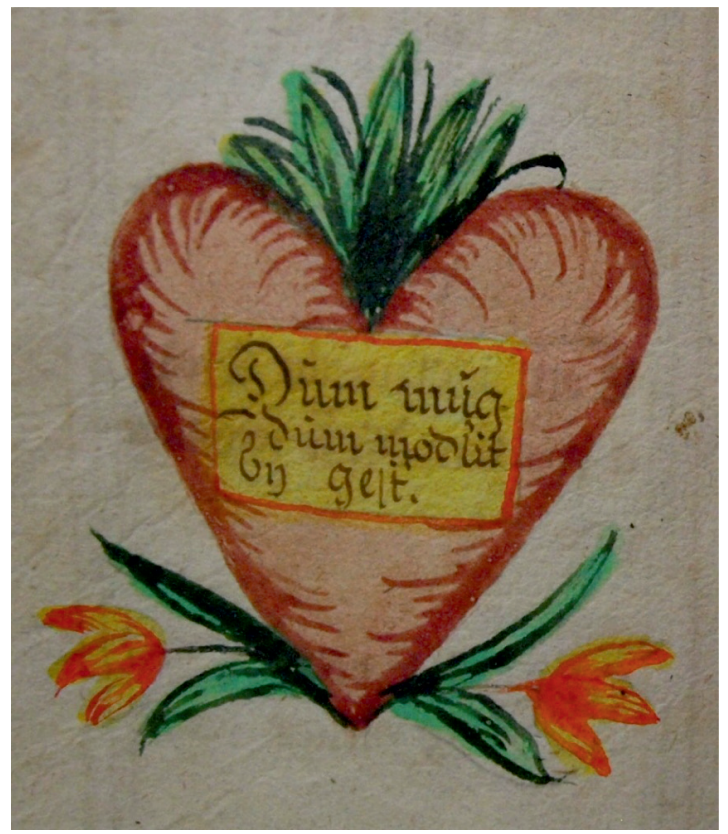

Obr. 2 Srdce s biblickým veršem Dưm můj di̊m modlitby jest, Luk 19:46. (MMG Polička, RKPST, sign. K 66).

Fig. 2 Heart with quote from the Bible My house will be a house of prayer, Luk 19:46. (MMG Polička, RKPST, sign. K 66). 


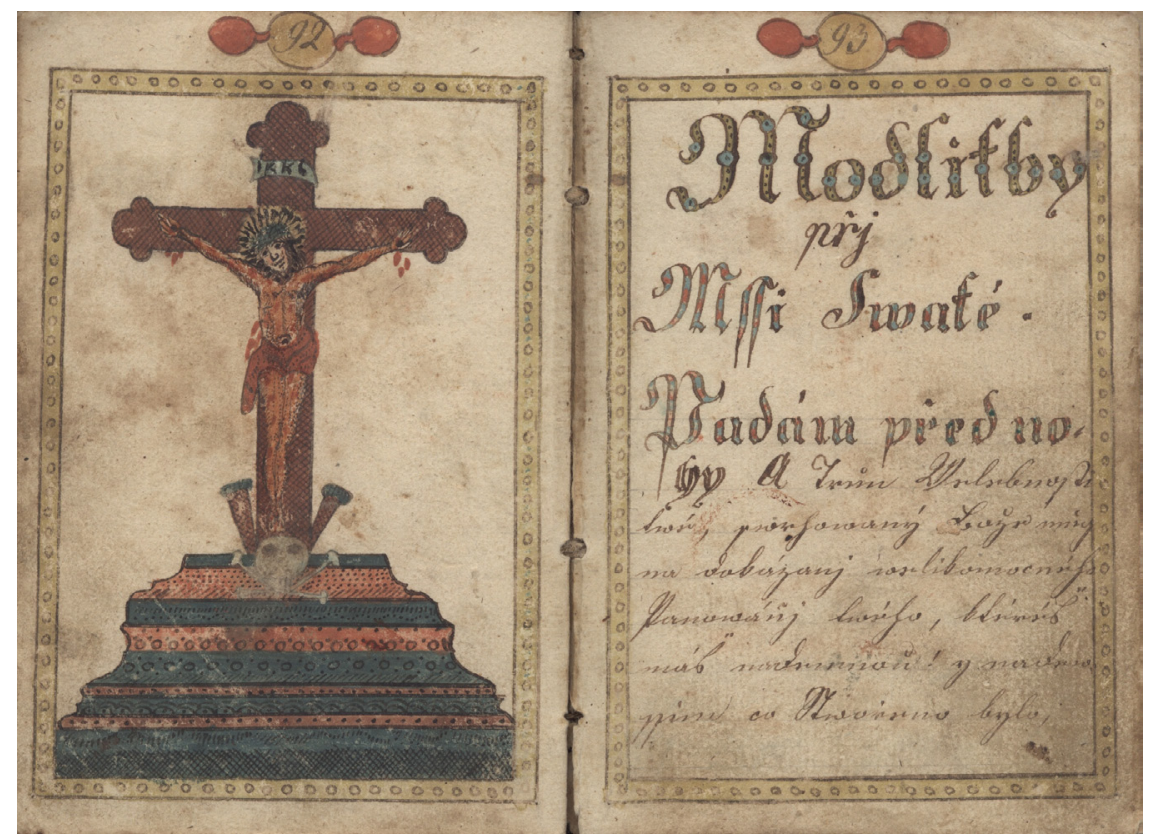

Obr. 3 Modlitby při Mši svaté (MZK, RKPST, sign. 1149.283, s. 92-93).

Fig. 3 Prayers at Holy Mass (MZK, RKPST, sign. 1149.283, p. 92-93).

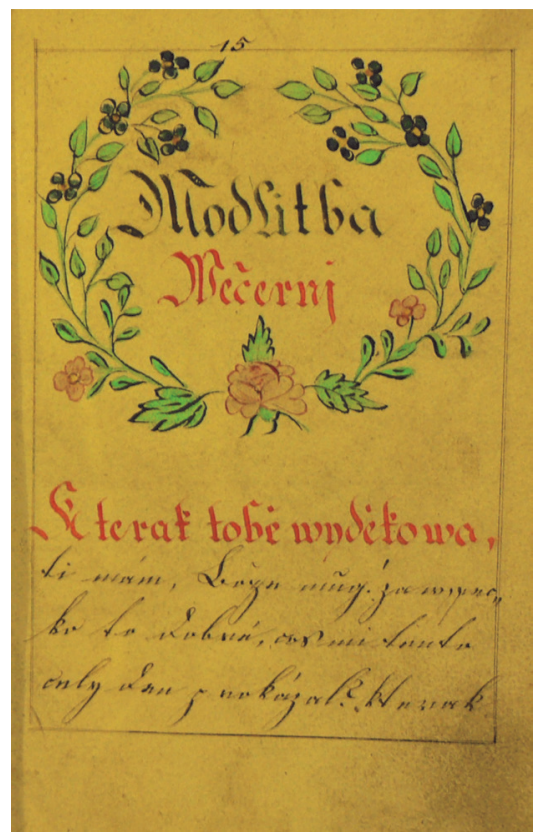

Obr. 4 Modlitba večerní (MZK, RKPST, sign. 1149.287, s. 15).

Fig. 4 Evening Prayer (MZK, RKPST, sign. 1149.287, p. 15). 